\title{
Analysis of above-ground steel storage tanks resting over piles or stone columns
}

\author{
Tarek Salem, Hassan Maaly, Ahmed Abdelbaset \\ Zagazig University, Department of Structural Engineering, Egypt. \\ nageeb2@yahoo.com,dr_h_maaly@yahoo.com,ahmed_mohammed_1281@yahoo.com
}

\begin{abstract}
Static and dynamic behavior of above-ground steel storage oil tanks resting on end bearing piles or stone columns are studied and analyzed using ADINA (2019) program. The studied soil profile is an upper soft clay soil layer, followed by an extended dense sand layer. The main purpose of this research is to explore to what extent stone columns can be used as an effective alternative to concrete piles under steel storage tanks. Therefore, many three-dimensional numerical models are conducted to analyze and study the performance of such tanks in both static and dynamic cases. Ten of the studied cases are steel tanks resting over stone columns with different numbers and properties. On other hand, one model studied the behavior of steel tank resting on large diameter concrete piles. Results indicate that stone columns can be used instead of end bearing piles as long as the computed settlements are safe. In addition, stone columns are behaving better than concrete piles in decreasing of hoop stress in tank shell. It is also noticed that stone columns with high elastic modulus are effective in reducing the sloshing height of the oil surface during earthquakes.
\end{abstract}

KEYwORDS. Steel Tanks; Stone Column; Piles; Soft Clay; ADINA.

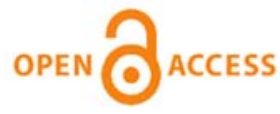

Citation: Salem, T., Maaly, H., Abdelbaset, A., Analysis of above-ground steel storage tanks resting over piles or stone columns, Frattura ed Integrità Strutturale, xx (2021) 4049.

Received: 30.03.2021 Accepted: 11.05 .2021 Published: 01.07.2021

Copyright: (C) 2021 This is an open access article under the terms of the CC-BY 4.0, which permits unrestricted use, distribution, and reproduction in any medium, provided the original author and source are credited.

\section{INTRODUCTION}

$\mathrm{C}$ oastal areas in many countries suffer from soft clay soils which cause a lot of problems to structures. In Egypt, many regions are covered with surface layers of soft clay such as zones in Alexandria, Port Said, Damietta and eastern Sinai. Two problems are associated with soft clays; high compressibility and low shear strength so that constructions over these soils cause problems to structures. Steel storage tanks resting on soft clay soil is a challenge for engineers because of their relatively higher loads, sensitivity for total and differential settlements, and containing high risk fluids. There are a lot of techniques which can be used to improve and reinforce soft clay soil. Concrete piled-raft foundations are the most popular solution for this situation because of their capacity in transmitting high loads. End bearing concrete piles carry the tank surface loads to the competent bearing soil layer. However, friction piles may be used for relatively light weight structures, where there is no hard layer to reach where the piles resist loads by their skin friction with the surrounding soil with slight end bearing values.

Although concrete piled-raft foundations are mostly used to support steel storage tanks under both static and dynamic cases, there is another economic alternative which is granular columns. Stone (granular) columns are one of the effective 
ground improvement techniques used to enhance saturated soft clay properties because of their relatively high capacity. In addition, their high permeability leads the columns to act as vertical drains to accelerate consolidation process of soft clay soil around stone columns [1].

Stone column is constructed by boring the ground and pouring gravel or stones into the pit to enhance the surrounding soft soil. Therefore, stone columns carry the largest part of load than surrounding weak soil because of their higher elastic modulus and stiffness $[1,2,3,4,5]$.

The behavior of steel storage tanks under static and dynamic loads is concerned by researchers because of damage which occur in both static and dynamic stages. Many tanks contained hazardous materials which may spill from tanks under dynamic excitations which lead to catastrophes. Other tanks contained petroleum materials which may cause fires and explosion and lead to kill a lot of people and plants and also affect human health. For example, Niigata and Alaska earthquakes in 1964 caused spillage of toxic and led to destructive fires. There were many types of failure were detected in steel storage tanks during past earthquakes like Imperial Valley (1979) and Northridge (1994). The main three types of failure of steel storage tanks were anchorage system failure, buckling in tank shell and foundation failure [6].

Many studies concentrated on the failure of tank itself such as anchorage failure, settlement and shell buckling however there is another essential problem occurs during earthquake. This problem is the sloshing or leakage of hazardous materials from the tank which may causes fires and environmental damage. Therefore, studies should introduce procedures to design steel storage tanks not only for strength condition but also for serviceability condition to prevent buckling, sloshing and uplift [7].

This study is an initial survey of the issue and focused on the nonlinear dynamic behavior of cylindrical above-ground steel oil tanks resting on Piled-Raft Foundation (PRF) or Stone Columns Foundation (SCF). Comparison between PRF and SCF are conducted in both static and dynamic analyses to explore the extent that SCF can be an effective alternative to PRF. Nonlinear time-history analysis using ADINA software are conducted to investigate the purpose of this research. Results of settlements; hydrostatic pressure, dynamic settlement, sloshing and hoop stresses are presented.

\section{NUMERICAL MODELING}

I $\mathrm{n}$ this section, three dimensional tank and soil models are established using nonlinear FEM analysis (ADINA software, 2019) to study the behavior of steel liquid storage tanks resting on piled-raft and stone column foundations. Soft clay soil is represented by Cam-Clay nonlinear soil model and the extended sand layer and stone columns are represented by Mohr-Coulomb soil model. Soil properties used in the analysis are presented in Tab. 1. Tank shell and its base are modeled as elastic isotropic material with properties of ASTM A516 steel Grade 70. The shell required thickness is designed by Variable-Design-Point Method and the 1-Foot Method as presented by API-650 (2014). In addition, elastic isotropic material model is used again to model the raft and piles with properties of reinforced concrete material. Tank content (oil) is modeled by 3-D fluid linear potential based element with free surface, with capability to consider fluidstructure interaction and applied acceleration. The specific gravity of the liquid (oil) included in the tank is supposed to be 0.9. Properties of concrete and steel used in this paper are presented in Tab. 2.

\begin{tabular}{rcc}
\hline Soil Properties & Soft clay soil & Sand soil \\
Poisson's ratio $(\nu)$ & 0.48 & 0.35 \\
Elastic modulus (E), & 2.00 & 50.0 \\
$\mathrm{MPa}$ & 16.00 & 19.0 \\
Unit weight, $\mathrm{kN} / \mathrm{m}^{3}$ & 0.25 & - \\
\hline Lambda $(\lambda)$ & & \\
\hline
\end{tabular}

Table 1: Properties of Soft Clay and Extended Sand Layers

The studied tanks are selected to have a typical diameter, $\mathrm{D}=16.0 \mathrm{~m}$ and height, $\mathrm{H}=10.0 \mathrm{~m}$ with an aspect ratio $(\mathrm{H} / \mathrm{D}$, height to diameter of the tank) equal to 0.625. Tank diameter and height are chosen due to its commonness in the petroleum fields. Raft thickness is considered to be $1.20 \mathrm{~m}$ resting on circular concrete piles or stone columns. Each pile or stone column has diameter of $1.20 \mathrm{~m}$ and length of $16.0 \mathrm{~m}$. Tanks are open-top with no attached roof. Thickness of the tank shell and base plate is considered to be 8.0 and $6.0 \mathrm{~mm}$, according to API standards, respectively. Fig. 1 shows the finite element model used in the studied cases. 


\begin{tabular}{ccc}
\hline Material Properties & Concrete & Steel \\
Poisson's ratio $(v)$ & 0.20 & 0.30 \\
Elastic modulus $(\mathrm{E}), \mathrm{MPa}$ & 20,000 & 200,000 \\
Unit weight, $\mathrm{kN} / \mathrm{m}^{3}$ & 25.00 & 78.00 \\
\hline
\end{tabular}

Table 2: Properties of Concrete and Steel Used in This Research

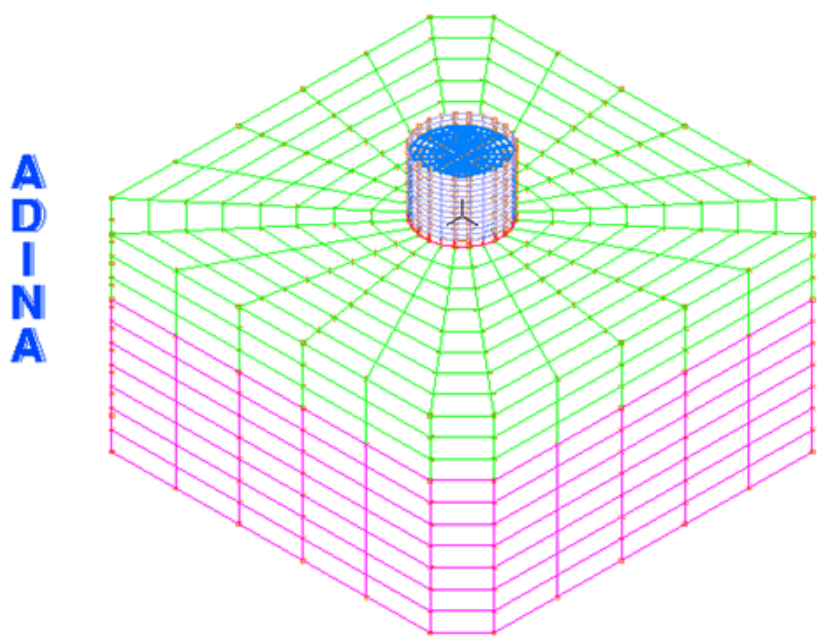

Figure 1: 3-D Finite element model for above-ground open top oil storage tank.

\section{Steps of finite element analysis}

Static and nonlinear dynamic time-history analyses are employed in order to study the behavior of the tanks.

Static analysis: This stage included defining materials and tank model, soil, foundation, liquid, and boundary conditions. Hydrostatic pressure and static hoop stresses could be obtained after this stage.

Time-history analysis: The seismic analysis is performed using Loma Prieta (1989) Earthquake record in terms of horizontal component acting at the lower boundary of the soil domain. Acceleration-time history of the earthquake record for Loma Prieta Earthquake is presented in Fig. 2.

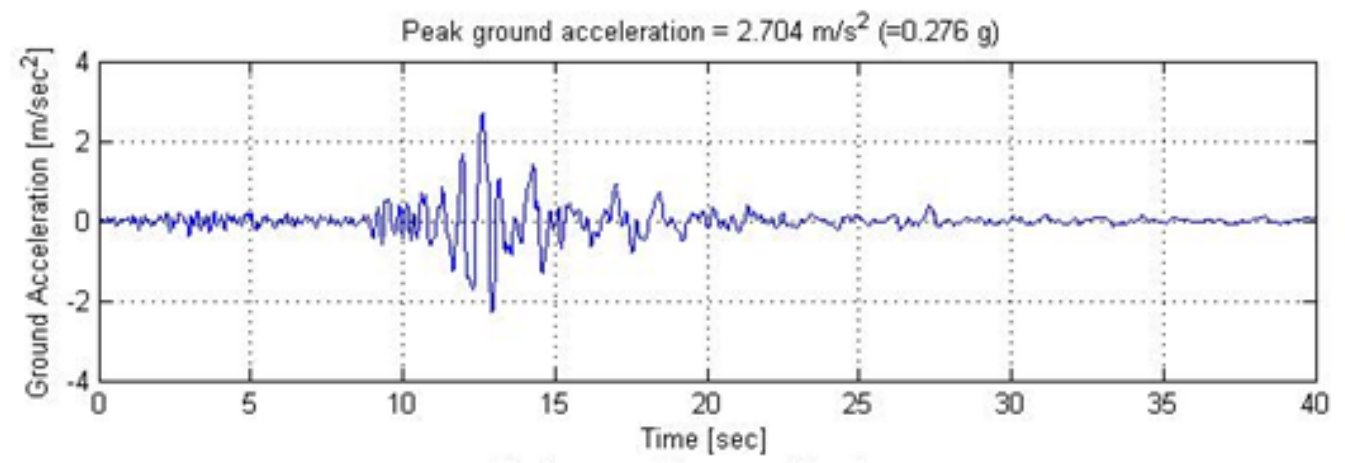

Figure 2: Acceleration-time history of the Loma Prieta earthquake, (1989)

\section{COMPARISON BETWEEN PRF AND SCF}

I

$\mathrm{n}$ this section, the behavior of steel storage above-ground tanks founded on either PRF or SCF are studied and analyzed to investigate the extent of stone columns effectiveness as an alternative to supporting the tanks constructed over soft clay soil. Tab. 3 presents the cases studied in this research. The elastic modulus of stone columns can be controlled (either increased or decreased) by controlling the compaction effort and energy utilized in 
compacting the stone columns. In addition, the materials of stone columns (sand, gravel or crushed stone) can also control the elastic modulus values.

\begin{tabular}{cccccc}
\hline Case & $\begin{array}{c}\text { Material of piles or } \\
\text { stone columns }\end{array}$ & $\begin{array}{c}\text { Elastic modulus, E } \\
(\mathrm{MPa})\end{array}$ & $\begin{array}{c}\text { Number of piles or } \\
\text { stone columns }\end{array}$ & $\begin{array}{c}\text { Unit weight, } \gamma \\
\left(\mathrm{kN} / \mathrm{m}^{3}\right)\end{array}$ & $\begin{array}{c}\text { Angle of friction } \\
(\varphi)\end{array}$ \\
\hline 1 & Concrete, PRF & 20,000 & 13 & 25.00 & 36 \\
2 & Stone, SCF2-13 & 50 & 13 & 19.00 & 38 \\
3 & Stone, SCF3-13 & 75 & 13 & 19.50 & 40 \\
4 & Stone, SCF4-13 & 100 & 13 & 20.00 & 42 \\
5 & Stone, SCF5-13 & 125 & 13 & 20.50 & 44 \\
7 & Stone, SCF6-13 & 150 & 13 & 21.00 & 36 \\
8 & Stone, SCF7-19 & 50 & 19 & 19.00 & 38 \\
10 & Stone, SCF8-19 & 75 & 19 & 19.50 & 40 \\
11 & Stone, SCF9-19 & 100 & 19 & 20.00 & 42 \\
\hline
\end{tabular}

Table 3: Properties of stone columns and piles used in this research.

\section{Static settlement}

Settlement due to static loads (weight of raft, tank and fluid) is very important factor in designing tanks or any building resting on weak soils because of local codes total and differential settlement limits. For example, Egyptian Code recommended a raft total settlement not exceeding $15 \mathrm{~cm}$ for buildings and tanks constructed in clay soil. The authors own opinion is that more strict total settlement limits should be applied for such strategic structures. Therefore, studying the settlement of steel storage tanks resting on soft clay soil is one of the main targets because the settlement controls the static design procedures in most cases.

In this study, the calculated settlements of tanks due to static loads for all studied cases are presented in Fig. 3. It is noticed that end bearing concrete piles are the most effective method in reducing static settlements of tanks with a total settlement value of $1.76 \mathrm{~cm}$. On the other hand, minimal number of stone columns (13 stone columns) having the lowest elastic modulus resulted in the maximum computed settlement in all cases with $12.80 \mathrm{~cm}$. Results also indicated that 19 stone columns with relatively high elastic modulus, e.g., $(\mathrm{E})=150 \mathrm{MPa}$ are the best effective alternative to concrete piles with total settlement value of $7.30 \mathrm{~cm}$. Thus, whenever increasing the number and the elastic modulus of stone columns, static settlement values consequently decrease. In all the studied cases, the computed settlement values do not exceed the allowable upper limit value.

\section{Hydrostatic pressure}

Color contour shading of the hydrostatic pressure for Case (3) is presented in Fig. 4. Results indicated that the maximum stresses occurred near the tank bottom. Results of the stone columns cases seem to have consistent small increase in the hydrostatic pressure where the maximum difference between stone columns cases and concrete piles case is not exceeding $1 \%$, as shown in Fig. 5. Therefore, using of stone columns with different number and elastic modulus instead of concrete piles do not cause a significant effect on hydrostatic pressure values, but rather tend to reduce the computed hydrostatic pressure values. 


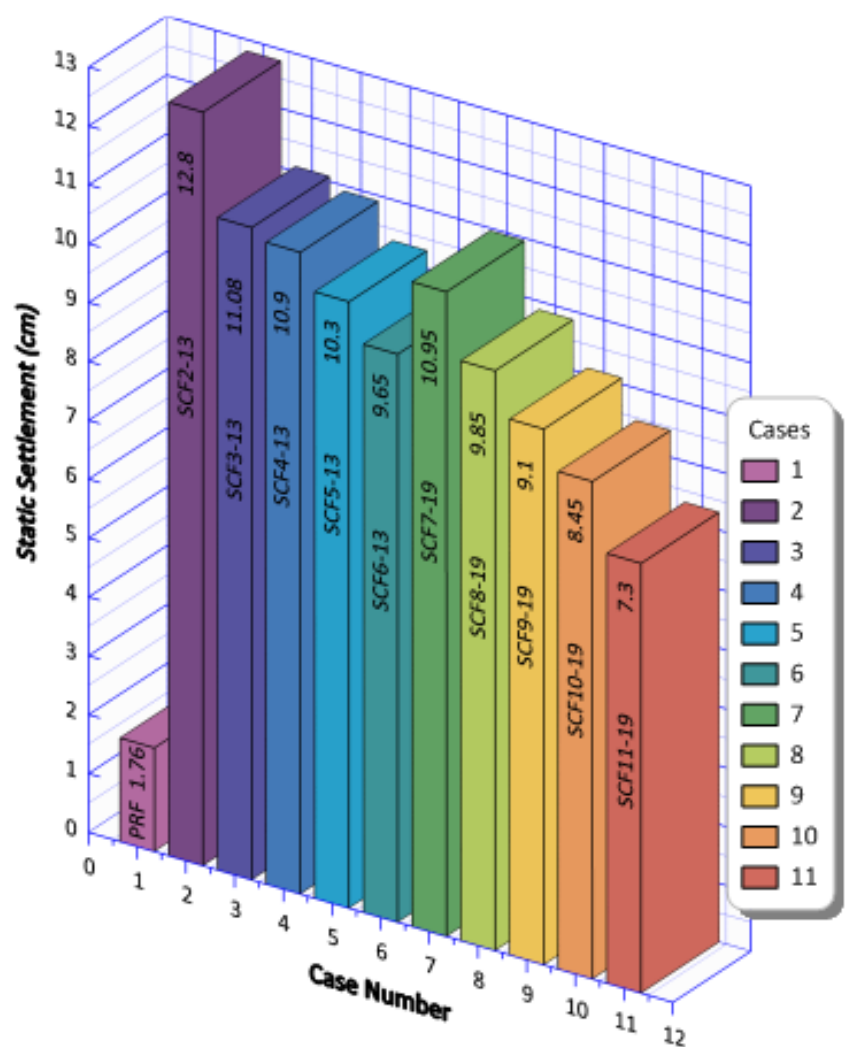

Figure 3: Comparison of static settlements for all the studied cases.

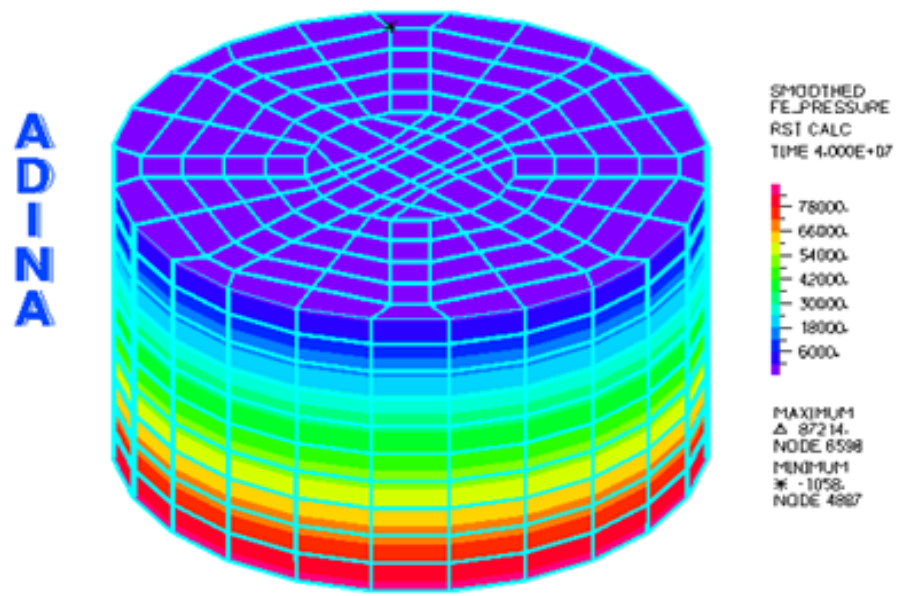

Figure 4: Color contour shading of hydrostatic pressure for case (3).

Settlement during the dynamic event

As stated earlier, settlement is a major factor that controls the behavior of all structures in both static and dynamic stages. In this section, maximum settlement of tanks due to earthquake loads are studied and analyzed. Fig. 6 shows the settlement-time history due to dynamic excitation for Case 1 (concrete piles) and Case 10. Results indicate that end bearing concrete piles resist the settlement due to earthquake excitations better than stone columns models. For concrete piles (Case 1), the dynamic settlements oscillate around zero with a maximum value of settlement equals to $1.35 \mathrm{~cm}$ at 28.6 sec. However, for stone column case SCF10-19, the dynamic settlements oscillate around $-1.00 \mathrm{~cm}$ and the maximum settlement value is equal to $3.38 \mathrm{~cm}$ at $38.5 \mathrm{sec}$ for (Case 10). Moreover, for stone columns also, small value of permanent settlement is noticed after the dynamic event calms down. It is also found that decreasing the number of stone columns 
resulted in decreasing the dynamic settlement as shown in Fig. 7. However concrete piles are better than stone columns in reducing dynamic settlement, but the values of dynamic settlement of stone columns models are still within reason.

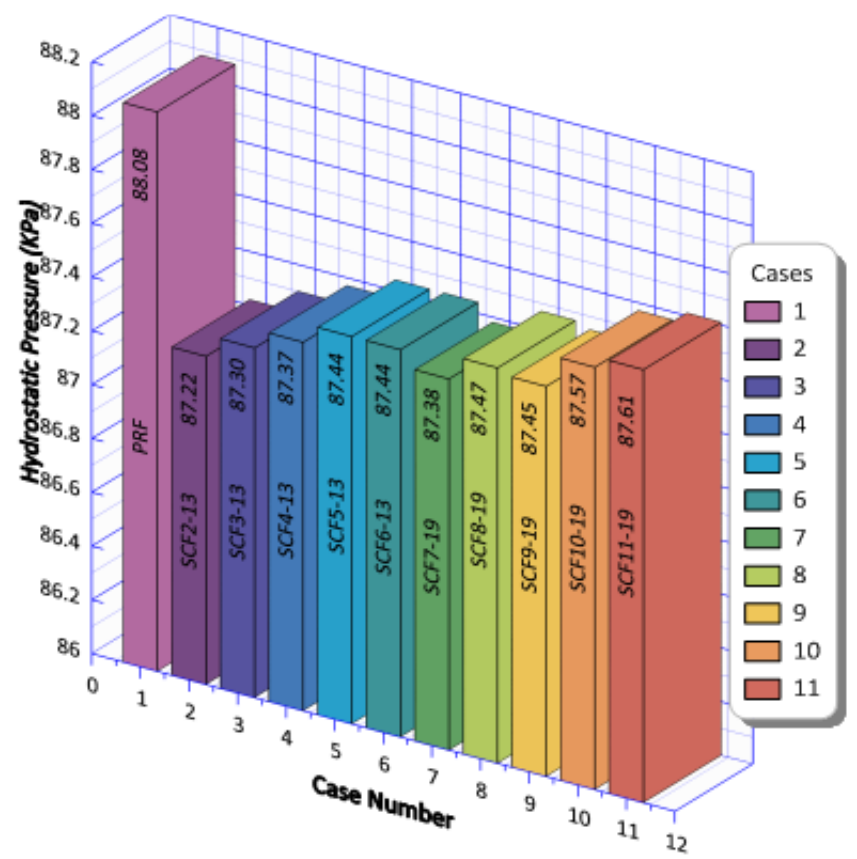

Figure 5: Comparison of hydrostatic pressures for the studied cases.

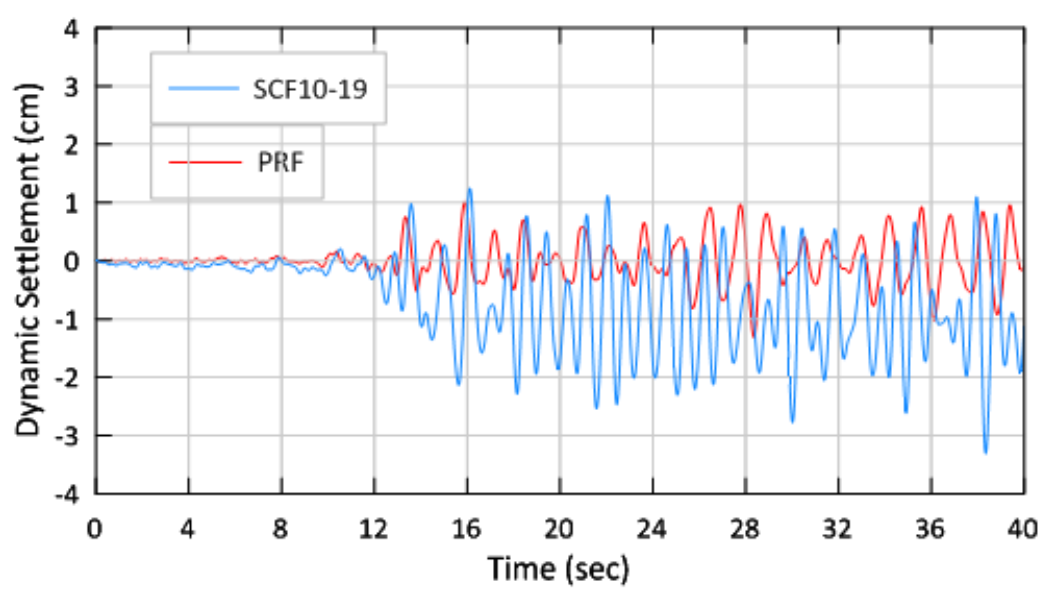

Figure 6: Variation of dynamic settlements with time during the dynamic event for cases (1) and (10)

\section{Hoop stresses in tank shell}

Elephant-foot buckling is defined as outward bulge above the tank base. It always occurs at the lower third of the tank shell at the location of maximum hoop stresses. Therefore, studying of hoop stresses generated in tank shell is very important to make sure that shell buckling is under control. It is noticed that stone columns are effective than concrete piles in reducing maximum hoop stresses in the tank shell, as shown in Fig. 8. The figure shows that the maximum hoop stresses decreased from 92.5 to $88.0 \mathrm{MPa}$, by about $5 \%$, when concrete piles (Case 1) are replaced by 13 stone columns with elastic modulus $=150 \mathrm{MPa}$ (Case 6). Therefore, stone columns are effective than concrete piles in this regard because of their low elastic modulus when compared with concrete piles. Slightly higher settlements under the tank center tend to reduce such stresses. It is also noticed that the maximum hoop stresses for all cases are found at about $1.0 \mathrm{~m}$ above the tank base. Fig. 9 presents the variation of hoop stresses with time during the dynamic excitation for Case 1 (concrete piles) and Case 8. For concrete piles (Case 1), the hoop stress oscillates around 80.9 MPa and the maximum value of hoop stress reach $92.5 \mathrm{MPa}$ at $39.4 \mathrm{sec}$. However the hoop stress oscillates around $80.3 \mathrm{MPa}$ and the maximum 
value of settlement touches $89.18 \mathrm{MPa}$ at $16.3 \mathrm{sec}$ for (Case 8). In general, lower stone column modulus resulted in relatively lower hoop stresses within the tank shell, as previously noted in the static analysis.

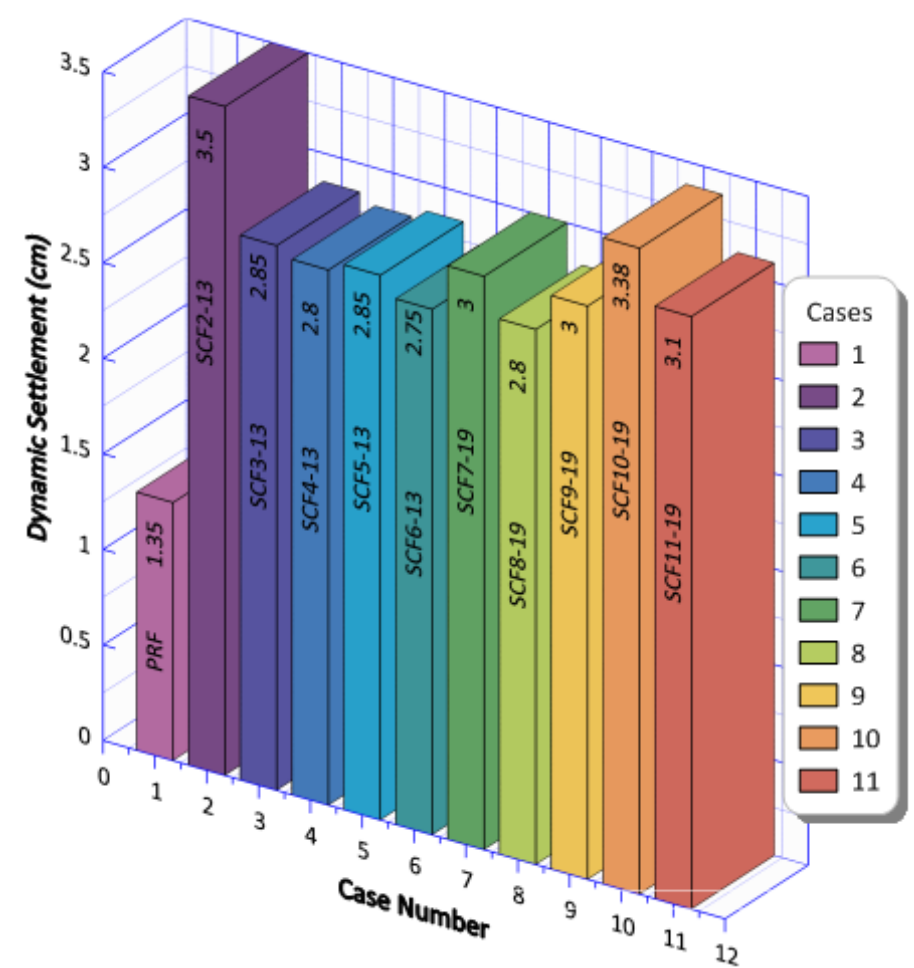

Figure 7: Comparison of dynamic settlements for the studied cases.

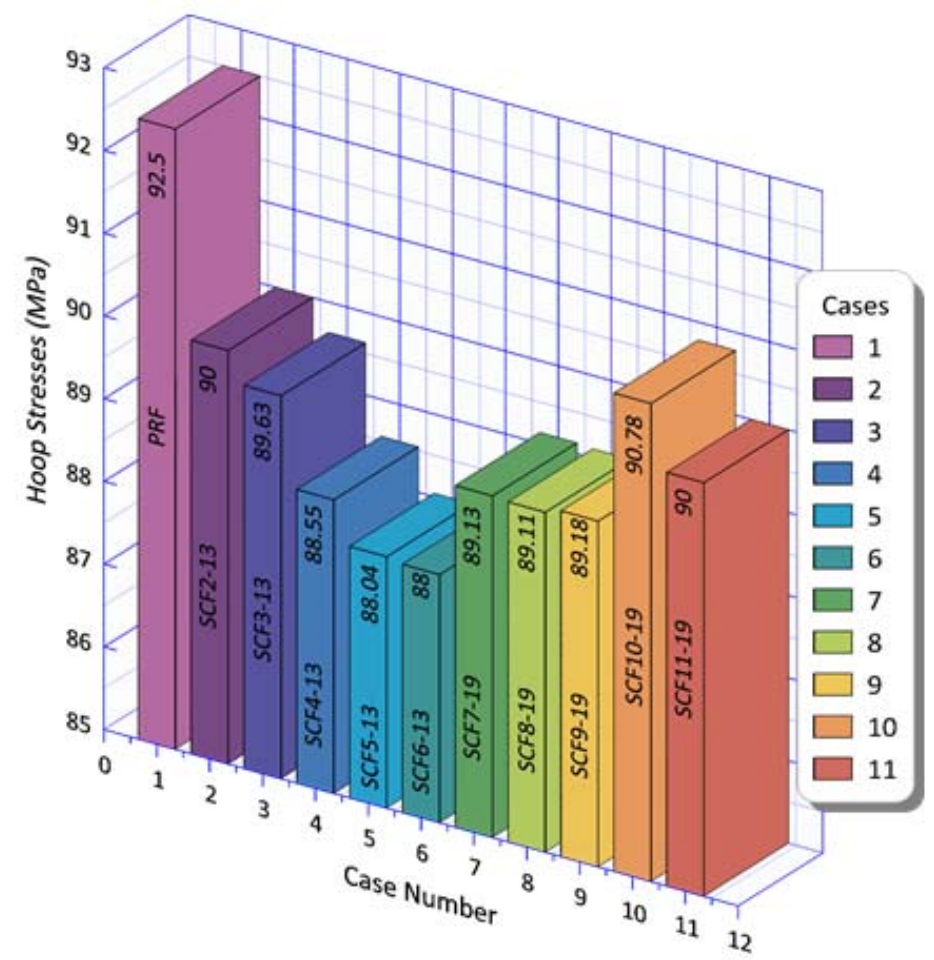

Figure 8: Comparison of hoop stresses values between all the studied cases. 


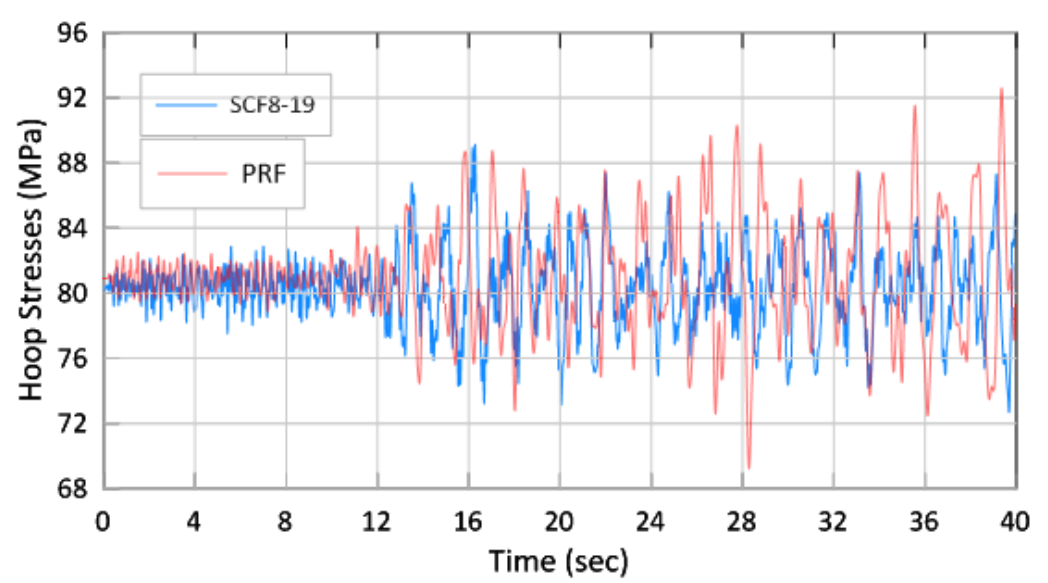

Figure 9: Variation of total hoop stresses in the tank shell with time during the dynamic event for cases (1) and (8).

\section{Sloshing}

Sloshing of liquid surface out of tank causes an enormous trouble such as fires and explosion because most ground tanks are used in storing chemical or hazardous materials. Therefore this research focuses on studying sloshing of fluids contained in tanks. It is noticed that sloshing height value decreased from 44.8 to $27.0 \mathrm{~cm}$ (by about $40 \%$ ) when concrete piles case (Case 1) is replaced by 19 stone columns with $\mathrm{E}=150 \mathrm{MPa}$ (Case 11), as shown in Fig. 10. Therefore, stone columns, especially with high elastic modulus, are better than concrete piles in reducing sloshing height values during earthquakes, and tend to dampen and soothe earthquake excitation. Fig. 11 presents variation of sloshing height with time due to dynamic excitation for Case 1 (concrete piles) and Case 11, which is 19 stone columns having the highest modulus. It is not just the maximum sloshing value, but the amplitude of variation of sloshing height along the whole earthquake excitation period in case of piles is clearly higher than those computed in the stone column case.

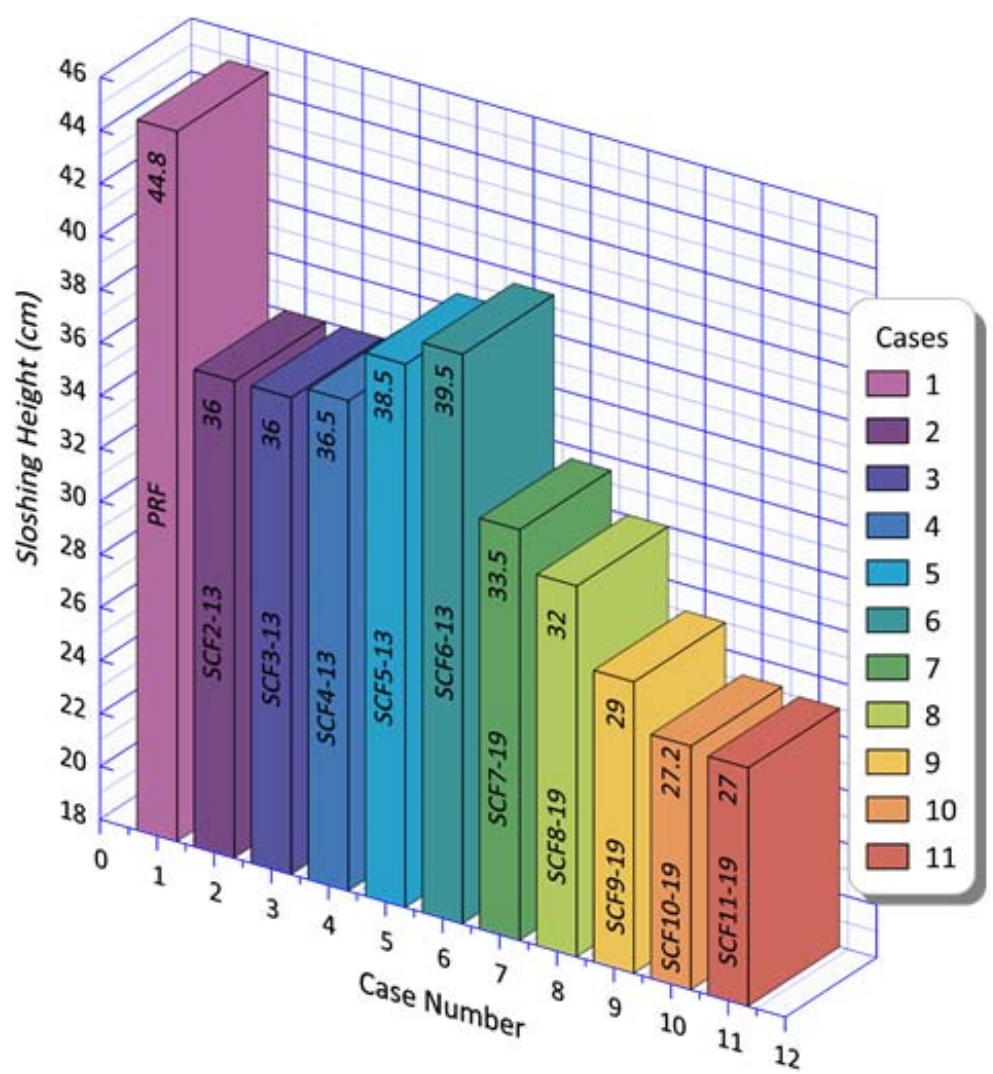

Figure 10: Comparison between sloshing heights for all the studied cases 


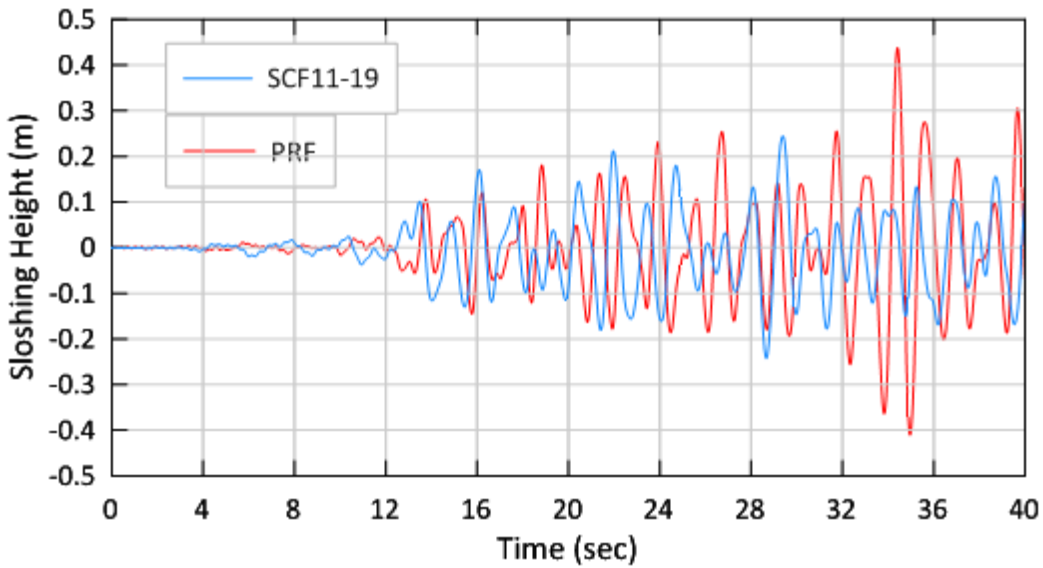

Figure 11: Variation of fluid sloshing height with time during the dynamic event for cases (1) and (11)

\section{CONCLUSIONS}

$\mathrm{B}$

2. Using reinforced concrete columns as tank foundations is more effective in reducing the static and dynamic settlements under such tanks. However, stone columns are behaving better than concrete piles regarding hoop stresses within the tank shell during static analysis and sloshing during the dynamic analysis for their ability to dampen (absorb) the earthquake excitation.

3. Calculated static settlements for concrete piles are equal to $1.76 \mathrm{~cm}$ for 13 concrete piles supporting the tank. However, this value becomes equal to $7.30 \mathrm{~cm}$ when using 19 stone columns, with relatively high modulus. In all cases, the static settlement values are safe and within the code limits.

4. The maximum settlement occurred during earthquake increases from $1.35 \mathrm{~cm}$ to $3.5 \mathrm{~cm}$ and $2.75 \mathrm{~cm}$ when the concrete piles replaced by Cases (2) and (6) stone columns, with about $1.0 \mathrm{~cm}$ permanent settlement for the stone column cases.

5. Using high elastic modulus stone columns instead of concrete piles has a significant effect in decreasing the sloshing height of liquid surface during the dynamic analysis. Sloshing height decreases by $40 \%$ when concrete piles are replaced by stone columns of larger number (from $13 \mathrm{RC}$ to $19 \mathrm{SC}$ ), with $\mathrm{E}=150 \mathrm{MPa}$.

6. Replacement of thirteen concrete piles by thirteen or nineteen stone columns caused a reduction in hoop stresses by small values of about $5 \%$. However, this change is only about $1 \%$ when calculating the hydrostatic pressure within the tank shell.

\section{REFERENCES}

[1] Dash, S.K. and Bora, M.C. (2013). Improved performance of soft clay foundations using stone columns and geocellsand mattress, Geotextiles and Geomembranes, 41, pp. 26-35.

[2] Hugher, J.M.O. and Withers, N.J. (1974). Reinforcing of soft cohesive soils with stone columns, Ground engineering, 7(3).

[3] Juran, I. and Guermazi, A. (1988). Settlement response of soft soils reinforced by compacted sand columns, Journal of Geotechnical Engineering, 114(8), pp. 930-943.

[4] Wood, D., Hu, W. and Nash, D.F. (2000). Group effects in stone column foundations: model tests, Geotechnique, 50(6), pp. 689-698.

[5] McKelvey, D., Sivakumar, V., Bell, A. and Graham, J. (2004). Modelling vibrated stone columns in soft clay, Proceedings of the Institution of Civil Engineers-Geotechnical Engineering, 157(3), pp. 137-149. 
[6] Roopkumdee, W. (2017). Buckling of liquid-filled steel storage tanks under earthquake loading, Dissertation, University of North Dakota, Grand Forks, North Dakota.

[7] Hafez, A. (2012). Seismic response of ground-supported circular concrete tanks, Dissertation, Civil Engineering Department, Ryerson University, Canada.

[8] API STANDARD (2014). Welded tanks for oil storage, Washington DC, American Petroleum Institute, USA. 